NBSIR 79-1922

An Interlaboratory Evaluation of the ASTM E 84-77a Tunnel Test Modified By the Consumer Product Safety Commission for Cellulosic Loose Fill Insulation

J. Randall Lawson

Center for Fire Research

National Engineering Laboratory

National Bureau of Standards

Washington, D.C. 20234

November 1979

Final Report

Prepared for:

U.S. Consumer Product Safety Commission Textile and Mechanical Engineering Group

$-Q C$ lethesda, Maryland 20202

100

.456 



\section{AN INTERLABORATORY EVALUATION OF THE ASTM E 84-77a TUNNEL TEST MODIFIED BY THE CONSUMER PRODUCT SAFETY COMMISSION FOR CELLULOSIC LOOSE FILL INSULATION}

J. Randall Lawson

Center for Fire Research

National Engineering Laboratory

National Bureau of Standards

Washington, D.C. 20234

November 1979

Final Report

Prepared for:

U.S. Consumer Product Safety Commission Textile and Mechanical Engineering Group Bethesda, Maryland 20202

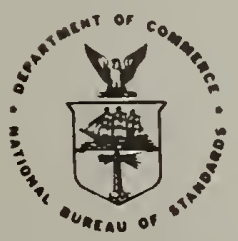

\section{U.S. DEPARTMENT OF COMMERCE}

Luther H. Hodges, Jr., Under Secretary

Jordan J. Baruch, Assistant Secretary for Science and Technology

NATIONAL BUREAU OF STANDARDS, Ernest Ambler, Director 

Page

LIST OF TABLES . . . . . . . . . . . . . . . . . . . . . . . iv

LIST OF FIGURES . . . . . . . . . . . . . . . . . . . . . . . . . iv

Abstract . . . . . . . . . . . . . . . . . . . . . . . . 1

1. INTRODUCTION . . . . . . . . . . . . . . . . . . . . . 2

2. TEST METHOD AND APPARATUS . . . . . . . . . . . . . . . . . . . 3

3. PARTICIPANTS . . . . . . . . . . . . . . . . . . . . . . . . 4 4

4. LABORATORY SURVEY . . . . . . . . . . . . . . . . . . . . . . 4

5. MATERIALS AND SAMPLE PREPARATION . . . . . . . . . . . . • • . . 6

6. EXPERIMENTAL DESIGN . . . . . . . . . . . . . . . . . . . . . 7

6.1 Test Procedure . . . . . . . . . . . . . . . . . . 7

6.2 Laboratory Specimen Preparation . . . . . . . . . . . . . . 7

6.3 Test Density . . . . . . . . . . . . . . . . . . . . 7

6.4 Order of Testing . . . . . . . . . . . . . . . . . . 8

7. TEST RESULTS AND DISCUSSION . . . . . . . . . . . . . . . . . 8

7.1 Statistical Procedures . . . . . . . . . . . . 8

7.2 Tunnel Test Data . . . . . . . . . . . . . . . . . . . . . . 8

7.3 Comparison of Fire Test Methods................ . 10

7.4 Variability ......................... . . . . . 10

8. SUMMARY AND CONCLUSIONS . . . . . . . . . . . . . . . . . 11

9. ACKNOWLEDGEMENTS . . . . . . . . . . . . . . . . . . . . 12

10. REFERENCES . . . . . . . . . . . . . . . . . . . . . . 13

APPENDIX A . . . . . . . . . . . . . . . . . . . . . . . . . A-1

APPENDIX B . . . . . . . . . . . . . . . . . . . . . . . . . B-1

APPENDIX C . . . . . . . . . . . . . . . . . . . . . . . . . . . c-1

APPENDIX D . . . . . . . . . . . . . . . . . . . . . . . D-1 
Table 1. Characteristics of the ASTM E 84-77a tunnels . . . . . . 14

Table 2. Tunnel test data, flame spread classifications (FSC) • . . 16

Table 3. E 84 Tunnel Test cell averages ordered from lowest to highest flame spread classification (FSC) . . . . . . . 17

Table 4. E 84 Tunnel Test results cell standard deviations ordered lowest to highest flame spread classification (FSC) . . . . 17

Table 5. Precision estimates of flame spread classifications (FSC) 18

Table 6. Comparison of precision estimates for fire test methods . 18

Table 7. Screen wire comparison using the modified ASTM E 84-77a test procedure... . . . . . . . . . . . . . . . 18

LIST OF FIGURES

Page

Figure 1. Example of E 84-77a tunnel used in the interlaboratory program .......................... 19

Figure 2. Details of the E 84-77a tunnel . . . . . . . . . . . 20

Figure 3. Cross section of tunnel at BB of figure 2 . . . . . . . . 21

Figure 4. Screen wire test frames in place on tunnel ledges . . . . 22

Figure 5. Screen test frames filled with cellulosic insulation before testing . . . . . . . . . . . . . . . 23

Figure 6. Examples of char and flaming observed by laboratories after test was completed . . . . . . . . . . . . 24 
AN INTERLABORATORY EVALUATION OF THE ASTM E 84-77a TUNNEL TEST MODIFIED BY THE CONSUMER PRODUCT SAFETY COMMISSION FOR CELLULOSIC LOOSE FILL INSULATION

\section{J. Randall Lawson}

Abstract

An interlaboratory evaluation was conducted to determine precision estimates for repeatability and reproducibility of the American Society for Testing and Materials (ASTM) E 84-77a tunnel test as modified by the Consumer Product Safety Commission for cellulosic loose fill insulation. Six laboratories participated in this study by running tunnel tests on eight cellulosic loose fill materials. Each laboratory was surveyed during the project to examine its conformance with the critical details of the test apparatus and procedure. The results of the survey showed that none of the tunnels completely conformed with the specifications of the modified ASTM E 84-77a standard.

The within-laboratory coefficients of variation for repeatability for the six fire-retardant treated cellulosic insulations ranged from 11 to 23 percent with an average of 16 percent. The between-laboratory coefficients of variation for reproducibility for the same materials ranged from 31 to 41 percent with an average of 35 percent. There would be little assurance that different laboratories would be able to distinguish between insulations which do and which do not comply with the CPSC mandatory level (FSC $\leq 25$ ) on a consistent basis.

Key words: Cellulosic insulation; flame spread; interlaboratory evaluation; precision; test methods; tunnel test. 


\section{INTRODUCTION}

The interim mandatory safety standard for cellulosic home insulation, which became effective on september $8,1978[1]^{1}$, requires that cellulosic insulation materials meet a prescribed flame spread classification (FSC) limit according to a specified standard fire test for flame spread. This test procedure is a Consumer Product Safety Commission (CPSC) modified version of the current ASTM E 84-77a test for surface burning characteristics of building materials [2]. This report is to provide precision estimates of repeatability ${ }^{2}$ and reproducibility ${ }^{3}$ associated with this fire test. Such estimates are required for several reasons:

a) To determine the degree of confidence which may be placed on numerical test results from a given number of replicate tests from an individual test laboratory.

b) To determine the extent of variability assignable to test results on "identical" specimens of a given insulation material tested in any tunnel conforming to the CPSC specifications.

An interlaboratory test program was conducted to evaluate the CPSC modified ASTM E 84-77a test procedure.

The purpose of the test procedure is to determine the comparative burning characteristics of a material by evaluating the flame spread over its surface when exposed to a standard test fire. The test should provide a basis for comparing surface burning characteristics of different materials.

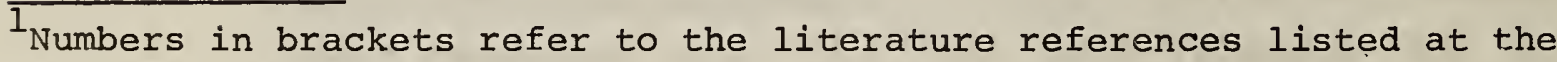
end of this report.

2 Repeatability precision - repeatability or within-laboratory precision is defined in terms of the variability between test results obtained in the same laboratory on the same material [3].

${ }^{3}$ Reproducibility precision - reproducibility of between-laboratory precision is defined in terms of variability between test results obtained in different laboratories on the same material [3]. 
The test procedure as specified by CPSC requires the use of the ASTM E 84 tunnel (see figures 1,2 and 3 ). CPSC made technical non-substantive changes to the test method. These modifications were primarily the addition of tolerances to a number of measurements on the tunnel. The purpose of these tolerances was to reduce allowable variations in the procedure and equipment. A list of these changes is presented in appendix A. Also, the CPSC standard does not require the evaluation of smoke development or $f$ uel contribution for these materials.

To briefly describe the tunnel test for cellulosic loose fill insulation, three metal frames $2.53 \mathrm{~m}$ ( $8 \mathrm{ft} 3-1 / 2 \mathrm{in}$ ) long and $51 \mathrm{~cm}$ (20 in) wide covered with steel wire screen, wires nominally $0.254 \pm 0.0254 \mathrm{~mm}(0.01 \pm 0.001$ in) in diameter with approximately $1.2 \mathrm{~mm}(3 / 64 \mathrm{in})$ openings, are placed end to end on the ledges of the test chamber (see figure 4). In this position the test frames with the wire mesh become the interior top surface of the tunnel. A sample of cellulosic loose fill insulation is spread at a relatively uniform density on the wire screens (see figure 5). The first $35.6 \mathrm{~cm}$ (14 in) of the specimen (that portion upstream of the burner) is covered with a piece of sheet metal. The specimen length exposed in the tunnel is $7.3 \mathrm{~m}(24 \mathrm{ft})$. The walls and floor of the tunnel are lined with fire brick. The tunnel has an inside width of $44.5 \mathrm{~cm}$ ( $17.5 \mathrm{in})$, a height of $30 \mathrm{~cm}$ (12 in) and a length of $7.6 \mathrm{~m}(25 \mathrm{ft})$. The tunnel is open at both ends; the "fire" and the "vent" end. The specimen, in a ceiling position with material supported by and exposed through the wire screen, is exposed to diffusion flames from two gas burners extending from the tunnel floor and pointed upward $30 \mathrm{~cm}$ (12 in) from the fire end. A forced draft induced by a blower and controlled by a damper system at the vent end of the tunnel pulls air through the opening upstream of the burners in the fire end. A prescribed average air velocity of 7.3 $\pm 1.5 \mathrm{~m} / \mathrm{min}(240 \pm 5 \mathrm{ft} / \mathrm{min})$ is measured at the vent end of the chamber prior to igniting the exposure flame. After ignition, a constant negative pressure (draft) is maintained and controlled by the damper system. The flame, which extends $1.36 \mathrm{~m}(4.5 \mathrm{ft})$ from the burner, and draft serve to ignite the specimen and to induce flame spread along the ceiling of the tunnel. Windows located on the side of the tunnel allow an observer to record the extent of flame spread as a function of time over the last $5.9 \mathrm{~m}(19.5 \mathrm{ft})$ of the $7.3 \mathrm{~m}$ (24 ft) specimen. The test duration is 10 minutes. The flame spread classification (FSC) is based on a scale which has 0 for asbestos-cement board and 100 for a selected grade of red oak flooring. A correction factor for the wire screen is determined by conducting tests on the red oak flooring with and without the screen. The FSC for the unscreened flooring divided 
by the value obtained with the screened flooring gives the screen correction factor (SCF). The FSC calculation takes into consideration the total area under the flame spread time-distance curve. The value developed from the area under the curve is then multiplied by the SCF to give the reported flame spread classification [2]. Fuel contribution and smoke development are not considered in this modified test procedure.

\section{PARTICIPANTS}

Five commercial testing laboratories and one private laboratory participated in this study. Appendix B lists the names of the participants. Each laboratory possessed a minimum of one year's experience with the tunnel. Several of the laboratories had experience that exceeded 20 years. However, few of the participants had more than four months' experience with the modified test procedure for cellulosic insulation. To maintain the participants' anonymity as it relates to their test results, the laboratories are assigned code numbers. In this report, the laboratory test data are identified only by the participants' code numbers.

\section{LABORATORY SURVEY}

Each participating laboratory was visited. Most of the visits were made before the testing was under way; however, because of time restraints, two visits were made while testing was in progress. The purpose of the laboratory survey was to determine the characteristics of the tunnels and to evaluate each laboratory's use of the test procedure. Table 1 lists the tunnel characteristics that were measured, and information obtained from the operators. As shown, the survey included an evaluation of tunnel dimensions, controls and instrumentation. When items were found to deviate from the specified value, the laboratories were informed so that changes could be made. Upon completing the survey it was found that none of the tunnels conformed completely with the CPSC or ASTM E 84-77a specifications. The asterisks on table 1 indicate the items that did not conform with the standard. Most of the tunnels did not conform with the standard because the turbulence bricks were not located where specified. Although it apparently has not been documented, it is believed that the air flow pattern in the tunnel is a critical factor in flame spread measurements and is affected by the placement of the bricks. A second area where the tunnel was often out of compliance was the placement of the end thermocouple. One laboratory did not use the prescribed wire size for the wire screen support. (See the discussion of wire mesh study in section 7.4). Another area of variability which indicates the possibility of some basic problems in the control of 
tunnel operating conditions is the wide heating rate range recorded by the participants. The standard calls for ar approximate $5.3 \mathrm{MJ} / \mathrm{min}$ (5000 BTU/min) heating rate for the tunnel burner. With this flow rate and maintaining other operating parameters such as air velocity, burner design and location, and tunnel geometry, the flame from the gas burner should extend $1.37 \mathrm{~m}$ $\pm 152.5 \mathrm{~mm}$ ( $4.5 \mathrm{ft} \pm 6 \mathrm{in}$ ) downstream. As shown in table 1 , the gas heating rate ranged from a low of $5.1 \mathrm{MJ} / \mathrm{min}(4805 \mathrm{BTU} / \mathrm{min})$ to $5.6 \mathrm{MJ} / \mathrm{min}(5290$ $\mathrm{BTU} / \mathrm{min})$. This represents a variation of almost $527 \mathrm{~kJ} / \mathrm{min}(500 \mathrm{BTU} / \mathrm{min})$ which is approximately $10 \%$ of the recommended heating rate. This type of variation could have a significant influence on the tunnel test results.

One potential problem that was observed which is not directly specified by the standards, as it relates to running the test, are variations in test room temperature and humidity. Some of the participating laboratories are located in cold climates and some are not. While observing tests in progress, it was noted that a number of tunnel operators were not able or did not attempt to maintain uniform temperatures and humidity conditions in the test room. In some cases, it is doubtful that consistent air supply temperature and humidity were maintained. This variation would result in changing air velocity in the tunnel. Significant variations were caused primarily by the opening of outside doors to remove samples from the tunnel test room and to vent smoke from the building. In one case it was snowing and the building doors were left open until the tunnel floor temperature was down to the prescribed $40.5 \pm 2.8^{\circ} \mathrm{C}\left(105^{\circ} \pm 5^{\circ} \mathrm{F}\right)$. At this time the building doors were closed, the sample placed in the tunnel, and the test was started. By this time, the $3.91 \mathrm{~m}(13 \mathrm{ft})$ floor thermocouple reading had dropped to $35.6^{\circ} \mathrm{C}$ $\left(96^{\circ} \mathrm{F}\right)$. It is known that the moisture content of paper and wood base materials varies with humidity (and temperature) level and is a significant factor in flame spread measurement.

In one laboratory, the tunnel air velocity was reset four times during a single day's operation because of changes in barometric pressure as a storm front approached the area. In other laboratories these adjustments are not routinely made.

The effects of some of the factors identified in the survey may have only a minor influence on the test results, but a combination of these factors may introduce significant differences. 
Six loose fill cellulosic insulation materials currently being sold in the home insulation market were chosen for the program. All of these materials are typically installed in home attics and wall cavities by blowing machines.

In addition, two cellulosic materials without fire-retardant chemical treatments were also chosen to provide a base line for comparative performance. Neither of these products are used as home insulation, but their visible characteristics are similar to fire-retardant treated cellulosic insulations. The materials were selected to provide a broad range of physical and chemical characteristics. Of the fire-retardant treated materials, the primary component of four materials was ground waste paper. The primary components for the other two treated materials were cotton fibers and ground wood chips. The processes for adding fire-retardant chemicals to the materials also varied. The chemicals for three of the waste paper materials were applied by dry mixing, and chemicals for the remaining waste paper product, the cotton product and the ground wood product were applied through wet processes. The primary components of the untreated cellulosic products were waste paper and ground wood.

Twenty-five bags of each material were obtained from the manufacturer. Upon receiving each product a code letter was assigned to the material. The code letters A through $H$ were used for identification. Each material was then blended using the following procedure. Twenty-five corrugated boxes containing two large plastic bags each were set out and numbered consecutively. Two plastic bags were used per sample box because a single bag was not large enough to hold the quantity required for a single tunnel test. The plastic bags were used to protect the specimens from moisture during shipment. A bag of material from group A was selected at random, weighed, and a fraction of the weight calculated which would produce an equal distribution of the product to each of the sample boxes. Samples of equal weight were taken from the material bag starting at the top and progressing to the bottom. The samples were distributed in consecutive order so that each box being filled received an equal portion. This procedure was followed until all of the samples from group A had been distributed. To ensure that each laboratory sample would represent an average cross section of the group, when the next bag within a product group was sampled the order of the laboratory sample boxes was indexed by one. This placed the top sample of the second bag from group A in box number two of the laboratory set and placed the last sample in box number one. Each material group was prepared using the above procedure. 
After the samples were mixed the boxes were weighed and the plastic bags were sealed. The samples were then placed into laboratory groups, lot numbers were recorded, and the boxes were prepared for shipment. Each box contained the equivalent sample weight of one manufacturer's bag of insulation. The original bag weights, as obtained from the manufacturer ranged from 11.4 to $18.2 \mathrm{Kg}(25$ to $40 \mathrm{lb})$. A total of 24 boxes of cellulosic materials were shipped to each participant, providing three boxes, sufficient for three replicate tests, for each of the eight materials.

\section{EXPERIMENTAL DESIGN}

\subsection{Test Procedure}

Each participating laboratory was shipped three samples of eight different cellulosic materials. A letter of instruction was also sent with a copy of the test procedure which was published in the August 8, 1978 Federal Register. The instructions pointed out that technical non-substantive changes had been made to the ASTM E 84-77a test procedure. The letter also requested that the laboratories strictly comply with part 1209.4(c) (9) regarding the attachment of the wire screen to the red oak flooring and explicit instructions were given for the procedure for developing the screen correction factor (SCF). See appendix $\mathrm{C}$ which describes the procedure used.

\subsection{Laboratory Specimen Preparation}

The laboratories were informed that each box, containing two plastic bags of insulation, represented one sample. It was requested that each sample of cellulosic material be blended by dumping the two bags of material into an insulation mixer/blower, mixed for a minimum of two minutes, and then blown. The material was to be blown into a container and then conditioned usirg the procedure specified in the standard.

\section{3 Test Density}

Since there was a significant difference in the physical properties of one material as compared to the others, two different test densities were specified. All specimens except material $\mathrm{H}$ were specified to be tested at $40 \mathrm{Kg} / \mathrm{m}^{3}\left(2.5 \mathrm{lb} / \mathrm{ft}^{3}\right)$ density with an allowable range between 38 and $42 \mathrm{Kg} / \mathrm{m}^{3}$ $\left(2.4\right.$ and $\left.2.6 \mathrm{lb} / \mathrm{ft}^{3}\right)$. It was requested that material $\mathrm{H}$ be tested at $\mathrm{a}$ nominal density of $24 \mathrm{~kg} / \mathrm{m}^{3}\left(1.5 \mathrm{lb} / \mathrm{ft}^{3}\right)$ with an allowable range of 22 to $26 \mathrm{Kg} / \mathrm{m}^{3}$ (1.4 to $\left.1.6 \mathrm{lb} / \mathrm{ft}^{3}\right)$. 


\subsection{Order of Testing}

Two red oak flooring reference tests were conducted first. The standard select red oak flooring used for calibrating the tunnel was supplied by the laboratory. One of the tests was conducted with the wire screen attached to the red oak flooring and one was conducted without the screen. After the initial tunnel calibration with the red oak, the cellulosic materials were tested. When all of the cellulosic materials tests were completed, one additional screen covered red oak test was run. As shown in appendix $\mathrm{C}$, the screen correction factor was calculated using the screened and unscreened red oak test results.

\section{TEST RESULTS AND DISCUSSION}

\subsection{Statistical Procedures}

Six laboratories participated in the test program. Each laboratory ran three replicate tests on each of eight materials. The data generated by the participants were compiled and compared with the requirements of the CPSC interim safety standard. The standard states that any cellulosic insulation that is a consumer product must have a flame spread rating of 0 to 25 [1]. Also, the data were statistically analyzed using the methods presented in the "Tentative Recommended Practice for Conducting an Interlaboratory Test Program to Determine the Precision of Test Methods" which is being prepared by ASTM Committee E 11 [3]. Appendix D is a brief presentation of the statistical methods used in this report.

\subsection{Tunnel Test Data}

The data as received from the laboratories are presented in table 2 . This table exhibits the data cells ${ }^{4}$ which are made up of three replicate tests on each material. Of the materials tested, D and $F$ were not treated with fire-retardant chemicals. These products show test results with relatively wide ranges. One data unit located in cell $2 \mathrm{D}$ was not used in the statistical analysis. The laboratory reported that the test specimen did not fill the length of the tunnel, and the flames spread to the end of the specimen.

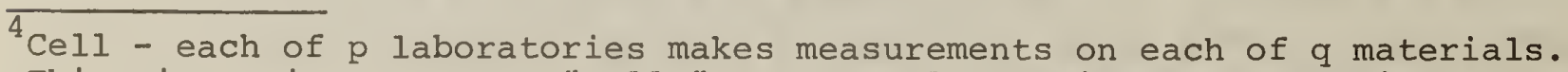
This gives rise to $p \times q$ "cells". Each cell consists of $n$ replicate measurements [3]. 
Also shown on table 2 are the results obtained for the select red oak calibration tests and the screen correction factors (SCF) used for calculating the flame spread classification numbers. The column of red oak calibration tests shows results for the unscreened and screened samples. The select red oak tested without the wire screen exhibits an FSC range of 93 to 116 with an average of 102 and a standard deviation of 8.8 . The screen covered red oak used for developing the correction factor has a range from 56 to 77 with an average of 68 and a standard deviation of 6.8 . The screen correction factors ranged from a low of 1.32 to a high of 1.63 with an average of 1.49 and a standard deviation of 0.11 . The data indicate that the procedure for calibrating the tunnel and developing the screen correction factor produced relatively uniform results.

Table 3 presents the mean values of each test cell with the materials ordered from the lowest to highest flame spread classification. The average flame spread classification for each material is shown at the bottom of the table. To the right of the cell averages are two columns which show the laboratory test results compared to the criteria set forth in the CPSC interim standard. For a material to pass, it must have a FSC $\leq 25$. As can be seen, the number of passing materials ranged from 0 to 6 . At the extremes, one laboratory passed all of the materials except the two untreated products, and two laboratories failed all of the materials. As shown in the table, the cell averages for materials $F$ and $D$ have a wide range. It is believed that part of the variation is the result of materials' non-uniformity, even though major efforts were made to blend materials from different bags. Part of the variation may also be due to environmental variables (humidity, temperature) which would be expected to be particularly sensitive for untreated cellulose.

Table 4 presents the cell standard deviations for each cellulosic material and laboratory. The pooled standard deviations are shown at the bottom of the table.

The precision estimates for the fire-retardant cellulosic materials flame spread classifications are given in table 5. For each material the table gives the average FSC and the coefficients of variation calculated for repeatability and reproducibility. The precision estimates for materials $F$ and $D$ which were not fire-retardant treated, are not included because the test was not under control for these materials as can be seen by the cell standard deviations in table 4. 
Looking at fire-retardant treated materials, it is apparent that a significant degree of variation exists. The range for the repeatability coefficient of variation is 11 to 23 with an average of 16 . The reproducibility coefficient of variation ranged from 31 to 41 and exhibits an average of 35 .

\subsection{Comparison of Fire Test Methods}

The author compared the precision of three test methods in a recent study involving the attic floor radiant panel [4]. The comparisons were made using data obtained from a report by Lee and Huggett concerning the ASTM E 84-70 tunnel test [5], results from a report by Benjamin and Adams involving the flooring radiant panel test [6], and data obtained from the attic floor radiant panel study on thermal insulation [4]. The conclusion from this comparison was that the attic floor radiant panel test precision was reasonable when compared to other fire test methods. To carry this comparison one step further, the precision of the data obtained from this study on the fire-retardant treated materials is compared with the precision of the other test methods (see table 6). Table 6 indicates that the CPSC modified ASTM E 84-77a test has a notably higher reproducibility coefficient of variation when compared to the other test methods. The results when compared with the attic floor radiant panel test show that the median coefficient of variation for reproducibility of the modified ASTM E 84-77a test method is $67 \%$ higher. It is also $30 \%$ greater than the median reproducibility coefficient of variation obtained with the ASTM E 84-70 test with carpet. Some of this variability as compared to the carpet materials can be attributed to the known random characteristics of the cellulosic materials.

\subsection{Variability}

Through test observations and data analysis, sources of variability that could influence the test results have been identified. The most significant variable influencing test results appears to be the two joints between the wire screen specimen frames. These joints are located at approximately $2.53 \mathrm{~m}$ ( $8 \mathrm{ft} 3-1 / 2 \mathrm{in}$ ) and $5.06 \mathrm{~m}$ (16 ft $7 \mathrm{in}$ ) as measured along the tunnel length from the fire end of the test chamber. Five laboratories reported the flame spread distance during the test, and the observed char distance and presence of flaming after the test. Out of 120 tests, 57\% indicated that these phenomena occurred within $30 \mathrm{~cm}$ ( $1 \mathrm{ft}$ ) of the test frame joint. Figure 4 shows a picture of the test frames with the screen wire joints open and sagging. Figure 6 shows examples of charring 
and flaming observed by laboratories after the tests were completed. In one case a laboratory reported that the screen joint appeared to interfere with the flame travel. Observation of the joints showed that the wire screen was generally loose and sagging after conducting two or three tests. One laboratory recognized this problem before starting the test program and reported bridging the test frame gaps with small pieces of wire screen. The test results from this laboratory showed the least variations associated with the test frame joints. Most of the laboratories used the same test frames throughout the entire program. Another problem also associated with the wire screen is its tendency to develop deep and random sags which alter the air flow patterns and localized radiation characteristics in the tunnel. Some sags in the wire screen were measured to be $3.8 \mathrm{~cm}(1.5 \mathrm{in}$ ) deep (below the normal plane of the specimen surface) and $25.4 \mathrm{~cm}$ (10 in) along the tunnel lengths.

Laboratory 3 attempted to avoid wire sag by using a stainless steel wire screen with a wire diameter of $0.508 \mathrm{~mm}(0.020 \mathrm{in})$. This screen does not meet the specifications but reduced the extent of sagging. A limited study was conducted to ascertain the effect on the FSC. Two sets of identical cellulosic insulation specimens selected consecutively from a manufacturer's production line were tested. The bags of insulation were randomized and shipped to the laboratory. The laboratory followed the test procedure as specified in the interlaboratory program except that one set of three specimens was tested with the large diameter stainless steel screen wire and the other tested using galvanized steel screen as specified in the standard (see table 7). As shown in the table, the large diameter stainless steel wire screen produced slightly lower but more uniform flame spread classification values than that obtained from the standard galvanized screen. At the completion of testing, it was noted that the galvanized screen wire had developed numerous irregularities while the stainless steel remained relatively flat and straight. This limited study supports the conclusion that wire screen sag increases test variability.

\section{SUMMARY AND CONCLUSIONS}

Six laboratories participated in an interlaboratory test program designed to determine the repeatability and reproducibility of the CPSC modified ASTM E 84-77a test procedure for cellulosic insulation as published in the August 8, 1978 Federal Register. Eight loose fill cellulosic materials were tested. For the six fire-retardant treated insulations the withinlaboratory coefficients of variation for repeatability ranged from 11 to 23 percent with an average of 16 percent, and the between-laboratory coefficient 
of variation for reproducibility ranged from 31 to 41 percent with an average of 35 percent. There would be little assurance that different laboratories would be able to distinguish between insulations which do and which do not comply with the CPSC mandatory level (FSC $\leq 25$ ) on a consistent basis. Part of the variability may be attributed to variability in the cellulose insulation material, including dispersion of the chemical fire retardant, and part can be attributed to problems with the wire screen specimen frames, such as sagging and irregular joints. Also, laboratory procedures for maintaining test room temperature, humidity, and exposure flame gas flow rates may have contributed to the variability. The coefficients of variation were significantly higher than those for the attic floor radiant panel.

\section{ACKNOWLEDGEMENTS}

Appreciation is extended to the cellulosic insulation manufacturers who provided material for the test program. Mr. Bernard Schwartz of the Consumer Product Safety Commission and the field offices assisted in obtaining the materials and arranging for their delivery to NBS. Mrs. Mary G. Natrella, Statistical Engineering Division, National Bureau of Standards, provided statistical consultation and Mr. Sanford Davis, Furnishings Flammability Research, National Bureau of Standards, provided assistance throughout the project. Messrs. Dennis Sullivan, Lee Dunlap, and Tom Prather of the Center for Fire Research, National Bureau of Standards, prepared the test specimens used in this project. 


\section{REFERENCES}

[1] Consumer Product Safety Commission, Interim Safety Standard for Cellulose Insulation Part 1209, Federal Register, Vol. 43, No. 153, August 8,1978 .

[2] Standard Test Method for Surface Burning Characteristics of Building Materials, ASTM E 84-77a, American Society for Testing and Materials, Philadelphia, Pa. (1978).

[3] Tentative Recommended Practice for Conducting an Interlaboratory Test Program to Determine the Precision of Test Methods, ASTM Committee E 11, American Society for Testing and Materials, Philadelphia, Pa. (1978).

[4] Lawson, J. R., Interlaboratory evaluation of the attic floor radiant panel test and smoldering combustion test for cellulose thermal insulation, Nat. Bur. Stand. (U.S.), NBSIR 79-1588 (February 1979).

[5] Lee, T. C. and Huggett, C., Interlaboratory Evaluation of ASTM E 84-70, Tunnel Test Applied to Floor Coverings, Journal of Testing and Evaluation, Vol. 3, No. 1, American Society for Testing and Materials, Philadelphia, Pa. (1975).

[6] Benjamin, I. A. and Adams, C. H., Proposed criteria for use of the critical radiant flux test method, Nat. Bur. Stand. (U.S.), NBSIR 75-950 (December 1975). 


\begin{tabular}{|c|c|c|c|c|c|c|c|}
\hline Characteristic & Standard & 1 & 2 & $\begin{array}{c}\text { Laboratories } \\
3\end{array}$ & 4 & 5 & 6 \\
\hline \multicolumn{8}{|l|}{ Tunnel } \\
\hline $\begin{array}{l}\text { Air inlet slit height, } \\
\text { (in) }\end{array}$ & $3 \pm 1 / 16$ & 3 & 3 & 3 & $31 / 16$ & 3 & $215 / 16$ \\
\hline $\begin{array}{l}\text { Slit to center line of } \\
\text { burner (in) }\end{array}$ & $54 \pm 5$ & $571 / 2$ & 56 & $543 / 4$ & $521 / 4$ & 52 & $505 / 8$ \\
\hline $\begin{array}{l}\text { Overall tumnel length } \\
\text { (ft, in) }\end{array}$ & $25 \pm 3$ & $25-1 / 2$ & $25-1 / 2$ & $25-15 / 8$ & 25 & 25 & $25-1 \quad 1 / 2$ \\
\hline $\begin{array}{l}\text { Number of turbulence } \\
\text { bricks }\end{array}$ & 6 & 6 & 6 & 6 & 6 & 6 & 6 \\
\hline $\begin{array}{l}\text { Location of bricks from } \\
\text { center line of bumer } \\
\text { (ft) window side } \\
\text { Location of bricks from } \\
\text { center line of bumer } \\
\text { (ft ) back side }\end{array}$ & $\begin{array}{r}7 \pm 0.5 \\
12 \pm 0.5 \\
20 \mp 0.5 \\
4.5 \pm 0.5 \\
9.5 \pm 0.5 \\
16.5 \pm 0.5\end{array}$ & $\begin{array}{c}6.50 \\
11.67 \\
19.33^{\star} \\
4.50 \\
9.67 \\
16.08\end{array}$ & $\begin{array}{r}3.25^{\star} \\
8.33^{\star} \\
14.25^{\star} \\
5.50^{\star} \\
10.75^{\star} \\
18.67^{\star}\end{array}$ & $\begin{array}{r}7.50 \\
12.50 \\
19.67 \\
4.50 \\
9.50 \\
16.17\end{array}$ & $\begin{array}{c}6.42^{\star} \\
11.50 \\
20.42 \\
4.58 \\
9.58 \\
15.67 \star\end{array}$ & $\begin{array}{c}6.50 \\
11.50 \\
19.08^{\star} \\
4.58 \\
9.83 \\
15.58^{\star}\end{array}$ & $\begin{array}{r}4.67^{\star} \\
7.29^{\star} \\
14.04^{\star} \\
9.67^{\star} \\
11.88^{\star} \\
18.00^{\star}\end{array}$ \\
\hline $\begin{array}{l}\text { Depth of tunnel floor, } \\
\text { (in) }\end{array}$ & $12 \pm 0.5$ & $11.50-11.75$ & $12.25-12.50$ & 12 & 12 & $11.75-12$ & $11.75-12$ \\
\hline \multicolumn{8}{|l|}{ Draft Control } \\
\hline Draft control auto/man & auto & auto & auto & auto & auto & auto & auto \\
\hline $\begin{array}{l}\text { Manometer location from } \\
\text { (ft, in) }\end{array}$ & 21 minimm & $21-6$ & $25-10$ & 21 & $25-10$ & 23 & $22-8$ \\
\hline $\begin{array}{l}\text { Typical manometer value, } \\
\text { (in } \mathrm{H}_{2} \mathrm{O} \text { ) }\end{array}$ & $\mathrm{N} / \mathrm{A}$ & 0.085 & 0.065 & 0.078 & 0.07 & 0.076 & $0.05-0.06$ \\
\hline \multicolumn{8}{|l|}{ Air Velocity } \\
\hline $\begin{array}{l}\text { Air velocity with lab } \\
\text { anemometer, (ft/min) }\end{array}$ & $240 \pm 5$ & 237 & 240 & 240 & 237 & 242 & 238 \\
\hline Type of anemometer & $\begin{array}{l}\text { thermal } \\
\text { anemameter }\end{array}$ & HW & $\mathrm{HW}$ & RV & HW & $\mathrm{HW}$ & $\mathrm{RV}$ \\
\hline $\begin{array}{l}\text { Air temperature at } \\
\text { measurement }\left({ }^{\circ} \mathrm{F}\right) \\
\text { Temperature }\end{array}$ & $73.4 \pm 5^{\circ} \mathrm{F}$ & 70 & 70 & 70 & 70 & 70 & 70 \\
\hline $\begin{array}{l}\text { Bumer center line to } \\
\text { centerlined thermo- } \\
\text { couple (ft, in) }\end{array}$ & $13 \pm 1 / 2$ & $13-1$ * & 13 & 13 & $13-1$ * & $13-1 / 2$ & 13 \\
\hline $\begin{array}{l}\text { Burner center line to } \\
\text { end thermocouple } \\
\text { (ft, in) }\end{array}$ & $23 \pm 1 / 2$ & $23-1$ * & $23-4$ * & $23-3 / 4$ * & 23 & $23-1 / 2$ & $22-11 \quad 1 / 2$ \\
\hline $\begin{array}{l}\text { Thermocouple post O.D., } \\
\text { (in) }\end{array}$ & $\mathrm{N} / \mathrm{A}$ & $1 / 4$ & $3 / 8$ & $5 / 16$ & $11 / 16$ & $11 / 16$ & $15 / 32$ \\
\hline $\begin{array}{l}\text { Unshielded length of } \\
\text { themocouple (in) }\end{array}$ & $3 / 8 \pm 1 / 8$ & $1 / 2$ & $5 / 16$ & $3 / 16^{*}$ & $1 / 4$ & $1 / 4$ & $1 / 4$ \\
\hline $\begin{array}{l}\text { Height of thenmocouple } \\
\text { junction from tunnel } \\
\text { top (in) }\end{array}$ & $1 \pm 1 / 32$ & 1 & $7 / 8^{*}$ & $3 / 4^{*}$ & 1 & $11 / 16^{*}$ & $7 / 8^{\star}$ \\
\hline $\begin{array}{l}\text { Junction type straight/ } \\
\text { twisted }\end{array}$ & OPT. & s & s & s & s & s & $\mathbf{s}$ \\
\hline Type of themocouple & $\mathrm{N} / \mathrm{A}$ & $\mathrm{CA}$ & $\mathrm{CA}$ & $\mathrm{CA}$ & $\mathrm{CA}$ & $\mathrm{CA}$ & $\mathrm{CA}$ \\
\hline $\begin{array}{l}\text { Ga. of thermocouple } \\
\text { Fuel }\end{array}$ & No. 18 AWG & 18 & 18 & 18 & 18 & 18 & 18 \\
\hline Gas type & $\begin{array}{l}\text { City or } \\
\text { bottled }\end{array}$ & $C G$ & CG & $C G$ & $\mathrm{BM}$ & BM & $\infty G$ \\
\hline Heating rate (Btu/min) & $\sim 5000 \mathrm{Btu} / \mathrm{min}$ & 4870 & 4970 & 5290 & 4805 & 4835 & 4955 \\
\hline Type of preheat & OPT & CG & CG & CG & $C G$ & $\subset G$ & CG \\
\hline
\end{tabular}




\begin{tabular}{|c|c|c|c|c|c|c|c|}
\hline Characteristic & Standard & 1 & 2 & $\begin{array}{l}\text { aboratories } \\
3\end{array}$ & 4 & 5 & 6 \\
\hline \multicolumn{8}{|l|}{ Wire Screen } \\
\hline Type of metal & steel & GS & SS & SS & GS & GS & GS \\
\hline Mesh opening (in) & $\sim 0.0469$ & $0.0591 t$ & $0.0591+$ & $0.0534 t$ & $0.0591 t$ & $0.0591 t$ & $0.0618+$ \\
\hline Wire size (in) & $0.01 \pm 0.001$ & 0.009 & $0.020 \star$ & 0.009 & 0.011 & 0.011 & 0.01 . \\
\hline \multicolumn{8}{|l|}{ Miscellaneous } \\
\hline $\begin{array}{l}\text { Smoke meter from end } \\
\text { of tunnel ( } \mathrm{ft} \text { ) }\end{array}$ & 16 to 40 & 22.5 & 34.7 & 28.9 & 39.7 & 31 & 27.9 \\
\hline Duct insulated yes/no & $Y$ & $\mathbf{Y}$ & $\mathbf{Y}$ & $\mathbf{Y}$ & $\mathbf{Y}$ & $Y$ & $Y$ \\
\hline $\begin{array}{l}\text { Leakage test conducted } \\
\text { (no./year) }\end{array}$ & & $6 \mathrm{SB}$ & $2 \mathrm{SB}$ & As needed & $12 \mathrm{SB}$ & $12 \mathrm{SB}$ & $2 \mathrm{SB}$ \\
\hline
\end{tabular}

*These characteristics do not meet the standards specified in the ASTM E 84-77a standard. tMeasurements made by microscopic means.
$\mathrm{BM}=$ Bottled methane
$C A=$ Chramel-alumel
$\propto \mathbf{C}=$ city gas
GS = Galvanized steel
$\mathrm{HW}=$ Hot wire anemaneter
$\mathrm{RV}=$ Rotating vane anemaneter
SS = Stainless steel
$\mathrm{SB}=$ Smoke bomb 
$\underline{\text { Lab }}$

Material

$\underline{A} \quad \underline{B} \quad \underline{C} \quad \underline{D}^{*} \quad \underline{E} \quad \underline{F}^{*} \quad \underline{G} \quad \underline{H}$

$\begin{array}{lllllllll}1 & 30.6 & 35.3 & 31.2 & 116.6 & 38.9 & 144.4 & 34.0 & 27.2\end{array}$

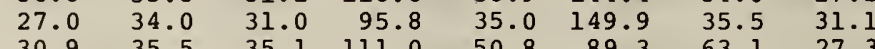

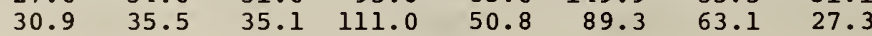

2

$\begin{array}{rrrrrrrr}16.6 & 10.7 & 12.9 & 162.0 & 20.6 & 60.1 & 19.9 & 15.0 \\ 12.8 & 12.7 & 15.0 & 56.7 & 8.0 & 50.0 & 16.2 & 8.2 \\ 4.3 & 13.3 & 12.2 & 61.4 & 16.2 & 53.9 & 8.1 & 12.3\end{array}$

3

$\begin{array}{llllllll}17 & 36 & 28 & 75 & 32 & 70 & 32 & 25 \\ 21 & 36 & 32 & 87 & 36 & 70 & 32 & 25\end{array}$

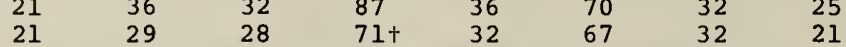

4

$\begin{array}{llllllll}28.5 & 40.9 & 36.8 & 95.5 & 32.8 & 77.4 & 36.7 & 24.5 \\ 28.5 & 36.7 & 32.7 & 85.0 & 28.6 & 77.2 & 32.7 & 24.4\end{array}$

$\begin{array}{llllllll}28.6 & 28.6 & 32.7 & 84.8 & 32.6 & 81.0 & 32.7 & 28.5\end{array}$

$\begin{array}{lllllllll}5 & 20.6 & 41.6 & 37.6 & 148.1 & 33.2 & 87.4 & 41.6 & 29.0\end{array}$

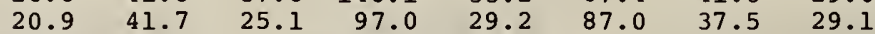

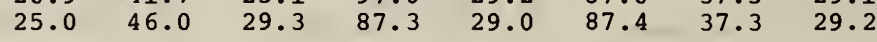

6

$\begin{array}{rrrrrrrr}8 & 26 & 31 & 108 & 23 & 210 & 36 & 18 \\ 10 & 31 & 18 & 181 & 26 & 408 & 26 & 13 \\ 18 & 28 & 23 & 271 & 26 & 96 & 36 & 13\end{array}$

* Cellulosic materials that were not treated with fire-retardant chemicals.

t This value was not used in the analysis. It was reported that the material did not extend the full length of the tunnel and the flames spread to the end of the specimen.

(s) Red oak flooring tested with wire screen.

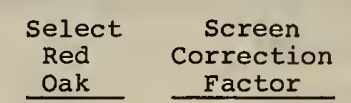

(s) 67.1

1.44

(s) 68.7

(s) 103.0

(s) 59.3

1.566

(s) 74 .

(s) 69

105.55

(s) 71.36

(s) 72.00

116.26

(s) 75.36

1.52

(s) 77.3

(s) 52.8

(s) 56.3

1.63 
$\underline{L a b}$

A $\quad$ H - C $-\frac{E}{B}-\frac{1}{B}$

$1 \quad 29.5$

28.5

32.4

41.6

13.4

14.9

34.9

29.0

33.0

12.2

\begin{abstract}
$\underline{G}$
\end{abstract}
44.2

F*

$\underline{F}^{*}$

D*

$54.7 \quad 93.4$

69.0

81.0

$78.5 \quad 88.4$

$35.4 \quad 34.0$

78.

88.4

$43.1 \quad 38.8$

87.3

110.8

28.3

32.7

238 .

186.7

31.3

$32.7 \quad 109.2 \quad 111.4$

$32.7 \quad 109.2 \quad 111.4$

column

20.

22.1

$27.3 \quad 29.4$

31.3

* Cellulosic materials that were not treated with fire-retardant chemicals.

Table 4. E 84 Tunnel Test results cell standard deviations ordered lowest to highest flame spread classification (FSC)

\begin{tabular}{|c|c|c|c|c|c|c|c|c|}
\hline$\underline{\mathrm{Lab}}$ & & & & Material & & & & \\
\hline & $\underline{A}$ & $\underline{\mathrm{H}}$ & $\underline{c}$ & $\underline{E}$ & $\underline{B}$ & $\underline{\mathbf{G}}$ & $\underline{F}^{*}$ & $\underline{D}^{*}$ \\
\hline 1 & 2.17 & 2.22 & 2.31 & 8.23 & 0.81 & 16.39 & 33.51 & 10.66 \\
\hline 2 & 6.30 & 5.06 & 1.46 & 6.40 & 1.36 & 6.04 & 5.09 & 58.48 \\
\hline 3 & 2.31 & 2.31 & 2.31 & 2.31 & 4.04 & 0.00 & 1.73 & 8.48 \\
\hline 4 & 0.58 & 2.34 & 2.38 & 2.37 & 6.25 & 2.31 & 2.14 & 6.12 \\
\hline 5 & 2.46 & 0.10 & 6.36 & 2.37 & 2.51 & 2.43 & 0.23 & 32.66 \\
\hline 6 & 5.29 & 2.89 & 6.56 & 1.73 & 2.52 & 5.77 & 157.87 & 81.65 \\
\hline $\begin{array}{l}\text { Pooled } \\
\text { Standard } \\
\text { Deviation }\end{array}$ & 3.74 & 2.88 & 4.12 & 4.62 & 3.43 & 7.63 & -- & -- \\
\hline
\end{tabular}

* Cellulosic materials that were not treated with fire-retardant chemicals. The wide range of cell standard deviations suggests that the test was out of control with these materials which makes it inappropriate to include pooled standard deviations. 
Table 5. Precision estimates of flame spread classifications (FSC)

\begin{tabular}{cccccc}
\hline $\begin{array}{c}\text { Treated } \\
\text { Material }\end{array}$ & $\begin{array}{c}\text { overall } \\
\text { Laboratory } \\
\text { Average }\end{array}$ & $\begin{array}{c}\text { Repeatability } \\
\text { Standard } \\
\text { Deviation }\end{array}$ & $\begin{array}{c}\text { Repeatability } \\
\text { Coefficient } \\
\text { of Variation }\end{array}$ & $\begin{array}{c}\text { Reproducibility } \\
\text { Standard } \\
\text { Deviation }\end{array}$ & $\begin{array}{c}\text { Reproducibility } \\
\text { Coefficient } \\
\text { of Variation }\end{array}$ \\
\hline A & 20.5 & 3.74 & 18.24 & 8.41 & 41.00 \\
H & 22.1 & 2.88 & 13.03 & 7.95 & 35.99 \\
C & 27.3 & 4.12 & 15.09 & 8.34 & 30.57 \\
E & 29.4 & 4.62 & 15.71 & 9.67 & 32.90 \\
B & 31.3 & 3.43 & 10.96 & 10.83 & 34.64 \\
G & 32.7 & 7.63 & 23.33 & 11.74 & 35.88 \\
Average & & & 16.06 & & 35.16
\end{tabular}

Table 6. Comparison of precision estimates for fire test methods

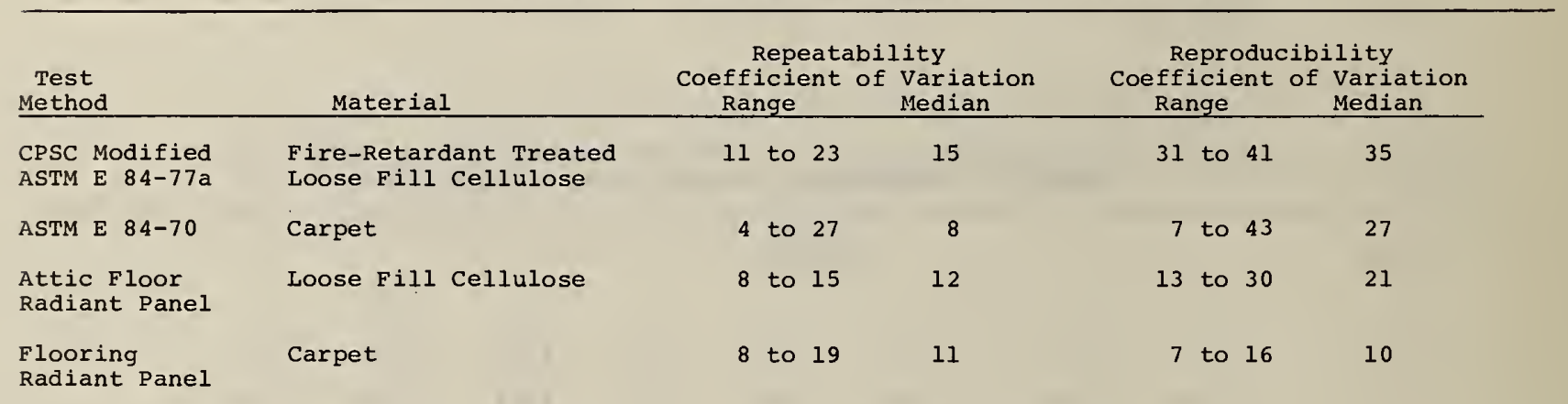

Table 7. Screen wire comparison using the modified ASTM E 84-77a test procedure

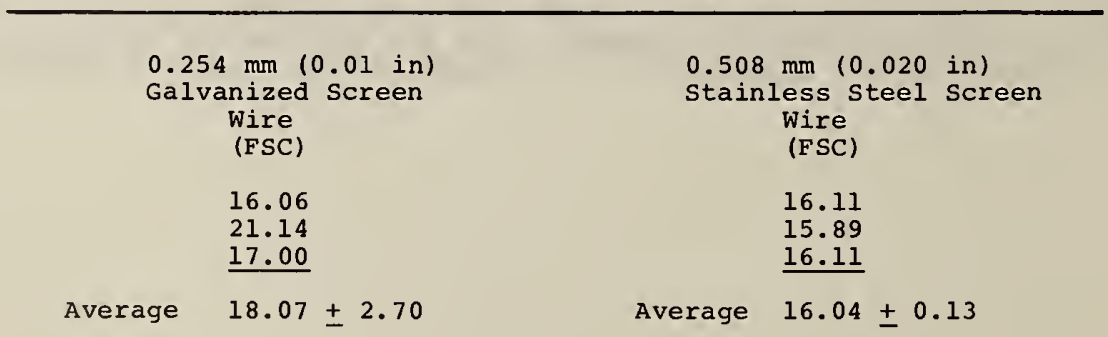




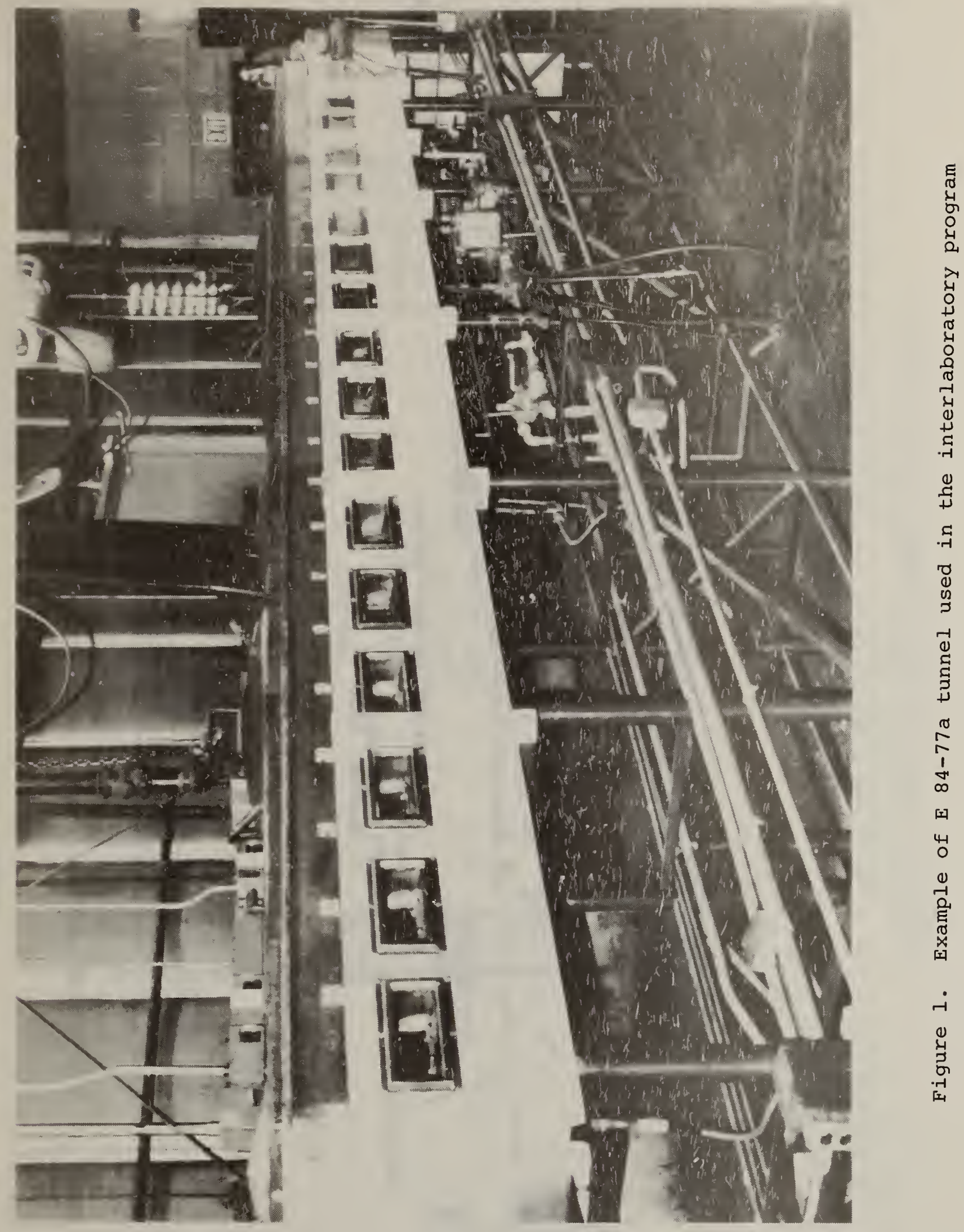



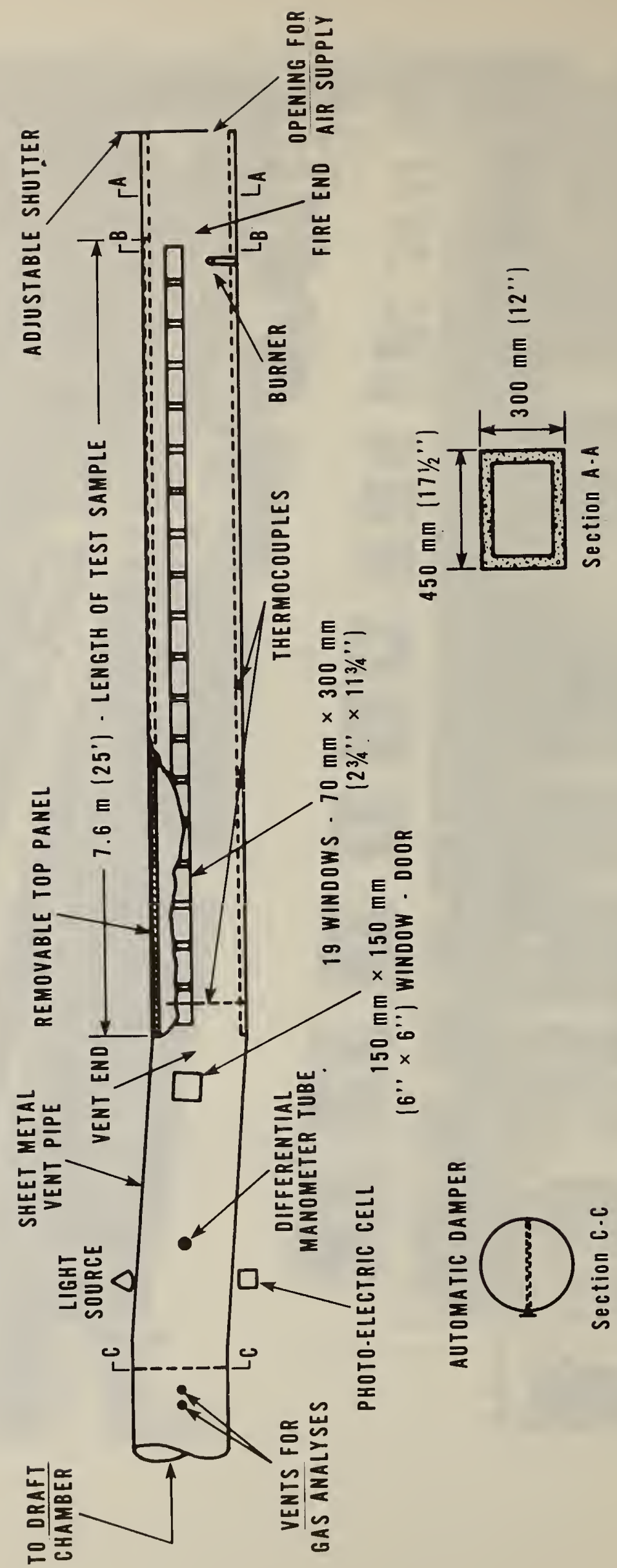


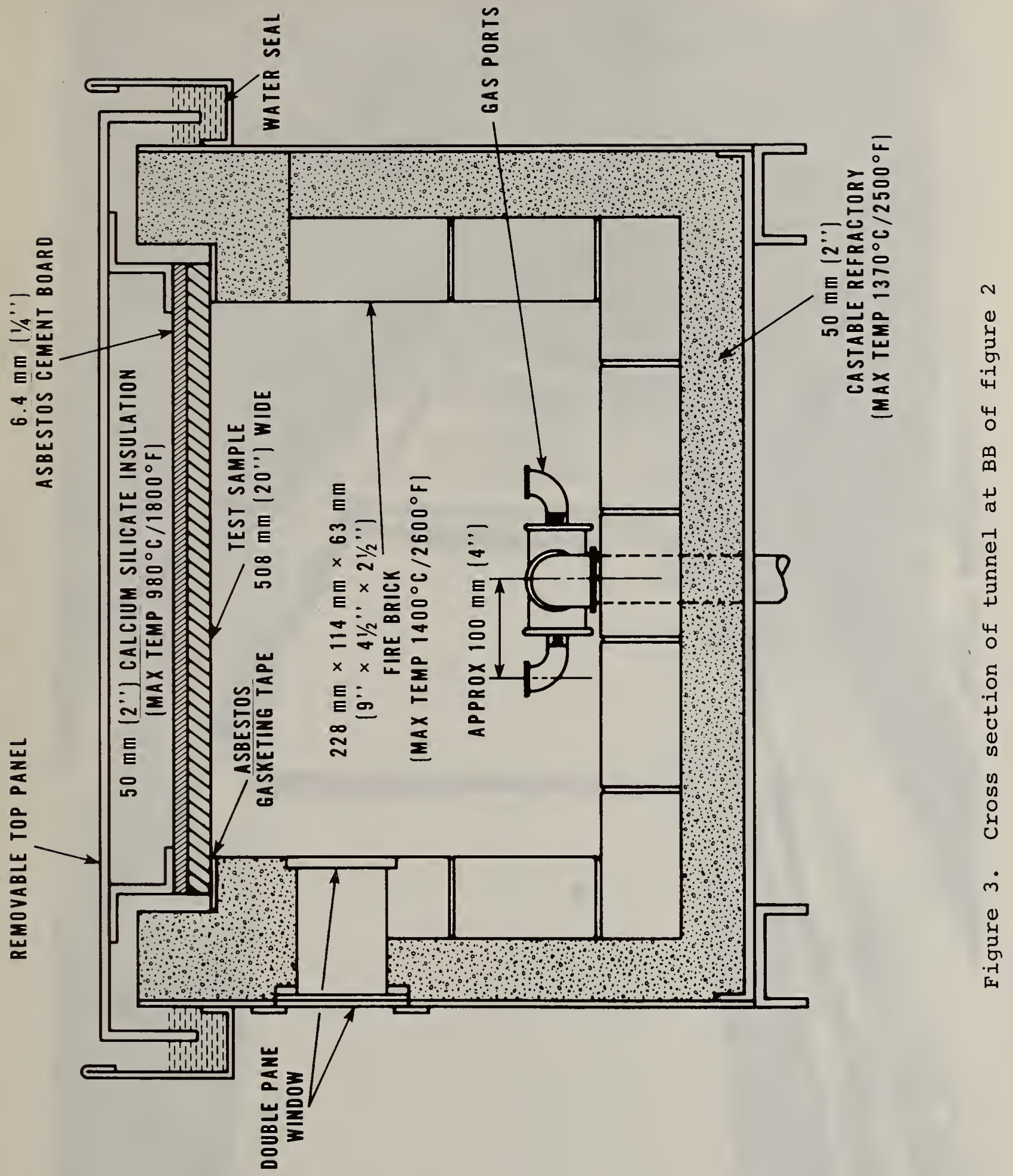




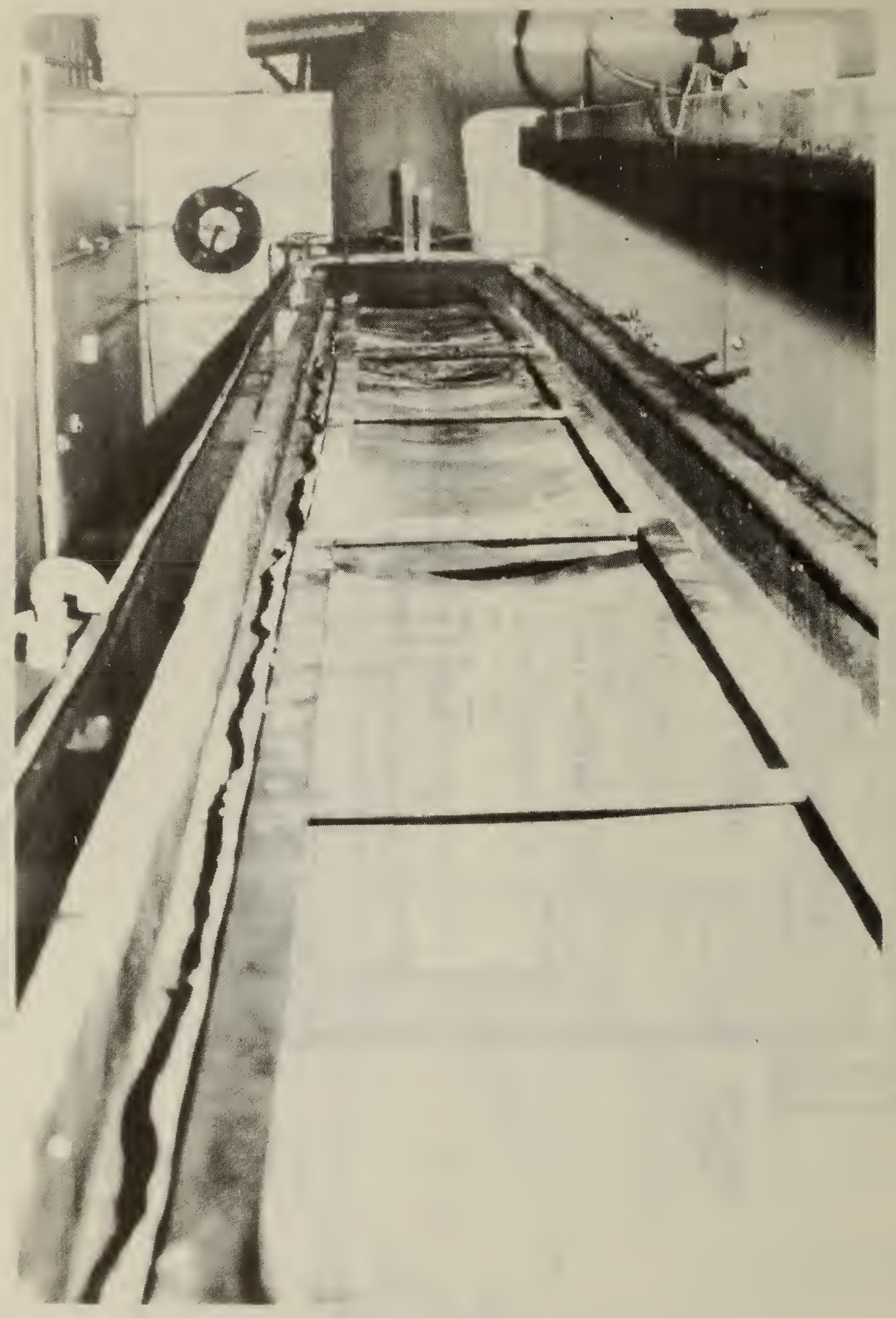

Figure 4. Screen wire test frames in place on tunnel ledges 


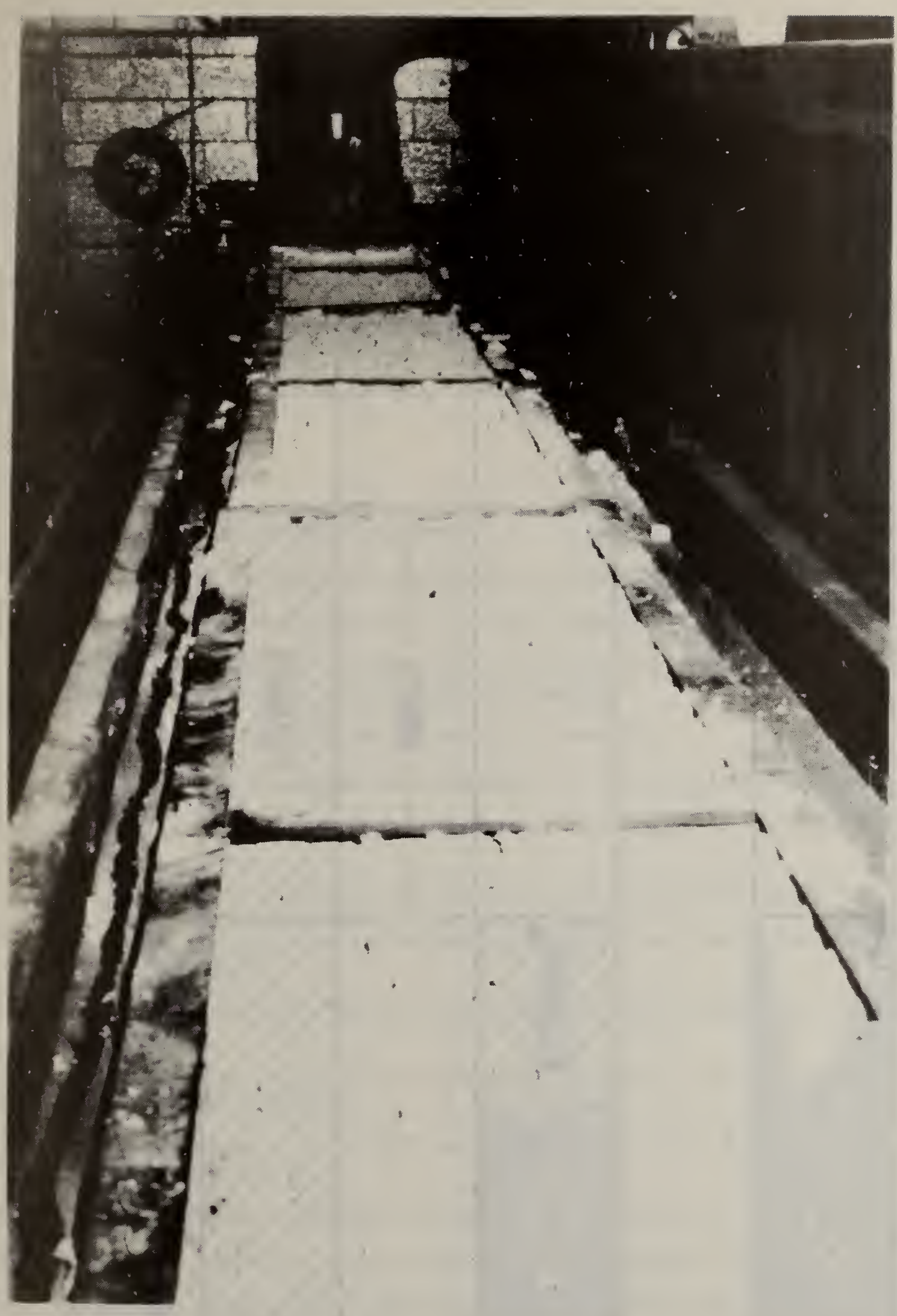

Figure 5. Screen test frames filled with cellulosic insulation before testing 

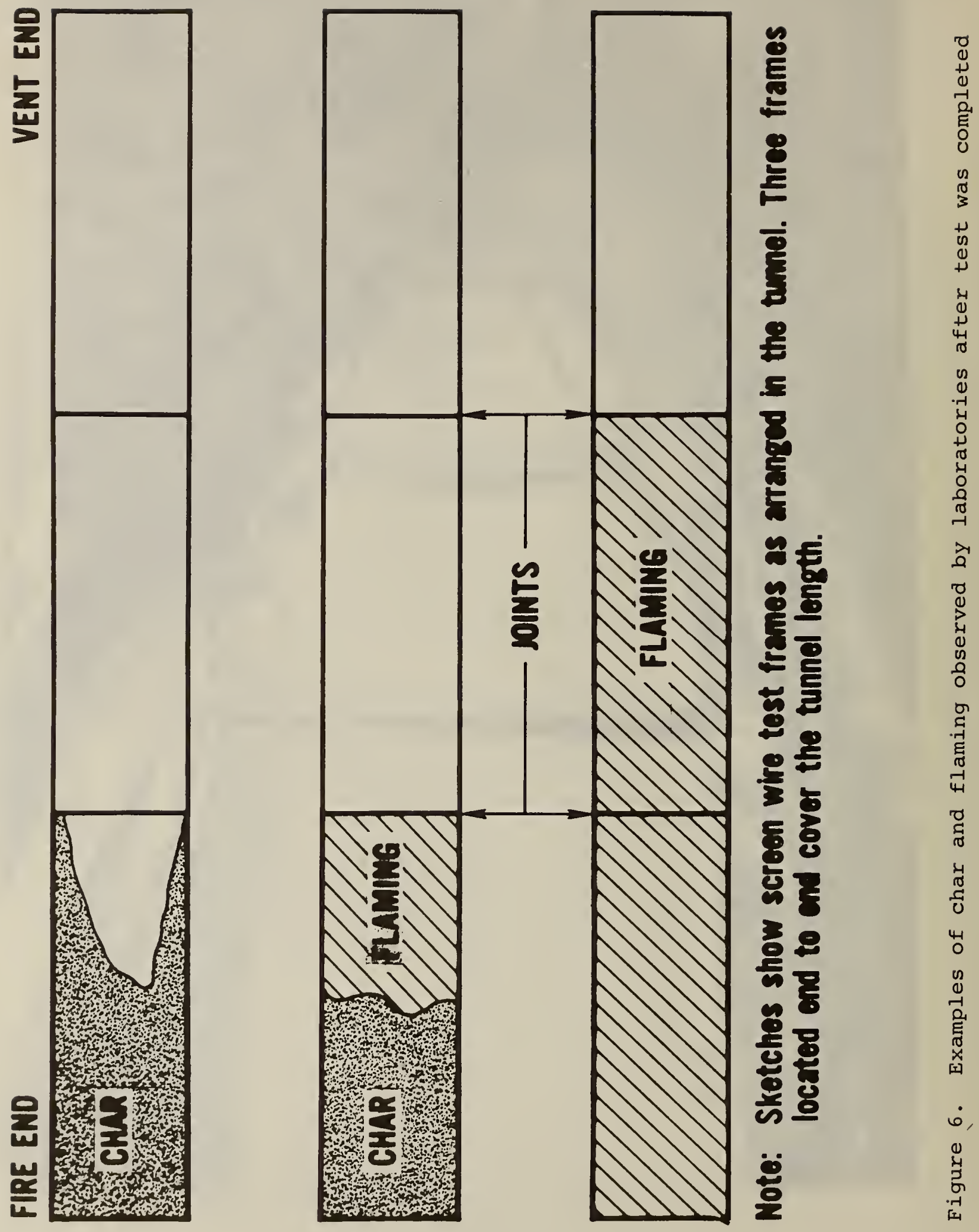
Technical Non-substantive Changes Made to the ASTM E 84-77a standard by CPSC

The Commission made these changes in order to:

(A) Ease some of the restrictive specifications for the test apparatus and test procedure,

(B) Simplify the test procedures,

(C) Eliminate provisions in the requirements that are unrelated to cellulosic insulation, and

(D) Increase the likelihood that consistent test results will be obtained.

\section{Changes}

1. Added the following tolerances:

$\pm 1 / 16$ inch to describe thickness of asbestos fabric gasket tape.

\pm 3 inches to describe the fire test chamber length.

Replaced a nominal 2 inches with a tolerance $3 \pm 1$ inch to describe the insulation for the top of the tunnel.

\pm 1 inch to describe the spacing of burners.

$\pm 1 / 4$ inch to describe the diameter of the vent end flue pipe.

$+1 / 16$ inch to describe the depth of the embedded thermocouple.

$-0$

$\pm 1 / 32$ inch to describe the asbestos cement board thickness.

\pm 1 inch to describe the distance from burner ports for recording the air velocity.

+6 inches to describe the distance the test flame must extend downstream.

\pm 6 inches to describe the distance intervals for making observations in calibration tests.

$\pm 1 / 4$ inch and $\pm 1 / 16$ inch to describe the test frame supporting the specimen holder.

\pm 2 seconds to describe the duration of the test.

2. Added (or deleted) the following statements for clarity:

Provision that allows operators to use draft gage tap inserted through top of tunnel fire end.

Added "nominal" to dimensions for steel test frame steel angles. Added word "nominal" to describe pipe elbow at burner outlet. 
An alternate air velocity reading range used for draft gage taps in top of tunnel fire end.

Corrected two typographical errors in the ASTM standard.

(a) Air velocity changed from "7.32" to $" 73.2 " \mathrm{~m} / \mathrm{min}$.

(b) Red oak flooring thickness changed from "23/32 inch" to "25/32 inch."

Changed description of screen wire from "galvanized steel" to

"steel" to allow stainless steel screen.

Loose fill insulation shall be placed on steel screening with wires normally $0.01+0.001$ in $(0.254 \mathrm{~mm} \pm 0.0254 \mathrm{~mm})$ in diameter with approximate $3 / \overline{6} 4$ in $(1.2 \mathrm{~mm})$ openings.

Steel screen correction factor (SCF).

A provision to allow the Commission to determine the density of cellulose insulation for test if manufacturers do not specify.

Deleted terms "delamination" and "shrinkage" as observed burning characteristics.

Deleted paragraph 8.1 providing for analysis of products of combustion. 
APPENDIX B

Participants

Factory Mutual Research Corporation

Norwood, Massachusetts

Hardwood Plywood Manufacturers Association

Arlington, Virginia

Southwest Research Institute

San Antonio, Texas

Underwriters' Laboratories, Inc.

Northbrook, Illinois

Underwriters' Laboratories, Inc.

Santa Clara, California

Warnock Hersey Professional Services Ltd.

Vancouver B.C., Canada 



\section{APPENDIX C \\ Calculation of Screen Correction Factor}

1. Determine the FSC of the select red oak without the screen using the method specified in ASTM E 84-77a sections 5, 6 and 7 .

2. Determine the FSC of the select red oak with the screen using the same method. Two (2) tests with the screen were conducted, one (1) before insulation is tested and one (1) after.

3. Take the average of the FSC with the screen.

4. Divide the FSC of the red oak without the screen (step 1) by the average of the values with the screen (step 3 ).

Example:

$\frac{\text { value without the screen }}{\text { average of values with the screen }} \frac{95}{65}=1.46 \mathrm{sCF}$

Note:

FSC - Flame spread classification

SCF - Screen correction factor 



\title{
APPENDIX D
}

\section{STATISTICAL METHODS}

\author{
Nomenclature
}

$\left(\mathrm{CV}_{\mathrm{r}}\right)$

$\left(\mathrm{CV}_{\mathrm{R}}\right)$

$d_{i j}$

$\mathrm{n}_{i j}$

$\mathrm{p}$

$\mathbf{s}_{i j}$

$\left(s_{L}\right)_{j}$

${ }^{\left(s_{r}\right)^{j}}$

$\left(s_{R}\right)_{j}$

(s $\bar{x}$ j

$x_{i j}$

$\vec{x}_{j}$

Coefficient of variation for repeatability (within-laboratory)

Coefficient of variation for reproducibility (betweenlaboratories)

Cell deviations from average

Number of replicates per cell

Total number of laboratories

Cell standard deviation

Component of variance between laboratories

Pooled standard deviation for repeatability

Standard deviation for reproducibility

Intermediate variance quantity

Average for cell $(i, j)$ where $i$ represents the laboratory and $j$ the material

Average for $j^{\text {th }}$ material for all laboratories 
Pooled Standard Deviation for Repeatability for the $j^{\text {th }}$ material:

$$
\left(s_{r}\right)_{j}=\sqrt{\frac{1}{p} \Sigma_{i} s_{i j}^{2}}
$$

Equation (1) is applicable only when the number of replicates is the same for each laboratory for a given material. Where there are missing replicates in one or more laboratories use equation (la).

$$
\left(s_{r}\right)_{j}=\sqrt{\frac{\Sigma_{i}\left(n_{i j}-1\right) s_{i j}^{2}}{\sum_{i}\left(n_{i j}-1\right)}}
$$

Coefficient of Variation for Repeatability:

$$
\left(\mathrm{CV}_{r}\right)=100 \frac{\left(\mathrm{s}_{r}\right)_{j}}{\bar{x}_{j}}
$$

Standard Deviation for Reproducibility:

First calculate the "deviations from average" for each cell $(i, j)$ :

$$
d_{i j}=x_{i j}-\bar{x}_{j}
$$

Then calculate the intermediate standard deviation quantity where:

$$
\left(s_{\bar{x}}\right)_{j}=\sqrt{\frac{\sum_{i}\left(d_{i j}^{2}\right)}{p-1}}
$$

Using $\left(s_{\bar{x}}\right)_{j}$ and $\left(s_{r}\right)_{j}$ calculate the "component of variance" between laboratories, where:

$$
\left(s_{L}\right)_{j}=\sqrt{\left(s_{\vec{x}}\right)^{2}-\frac{\left(s_{r}\right)^{2}}{n}}
$$

The variance of the total variability of a single test result on the $j^{\text {th }}$ material including both within and between laboratory variability is given by:

$$
\left(s_{R}\right)_{j}=\underbrace{}_{D-2}
$$


Coefficient of Variation for Reproducibility for the $j^{\text {th }}$ material:

$$
\left(C V_{R}\right)_{j}=100 \frac{\left(s_{R}\right)_{j}}{\bar{x}_{j}}
$$




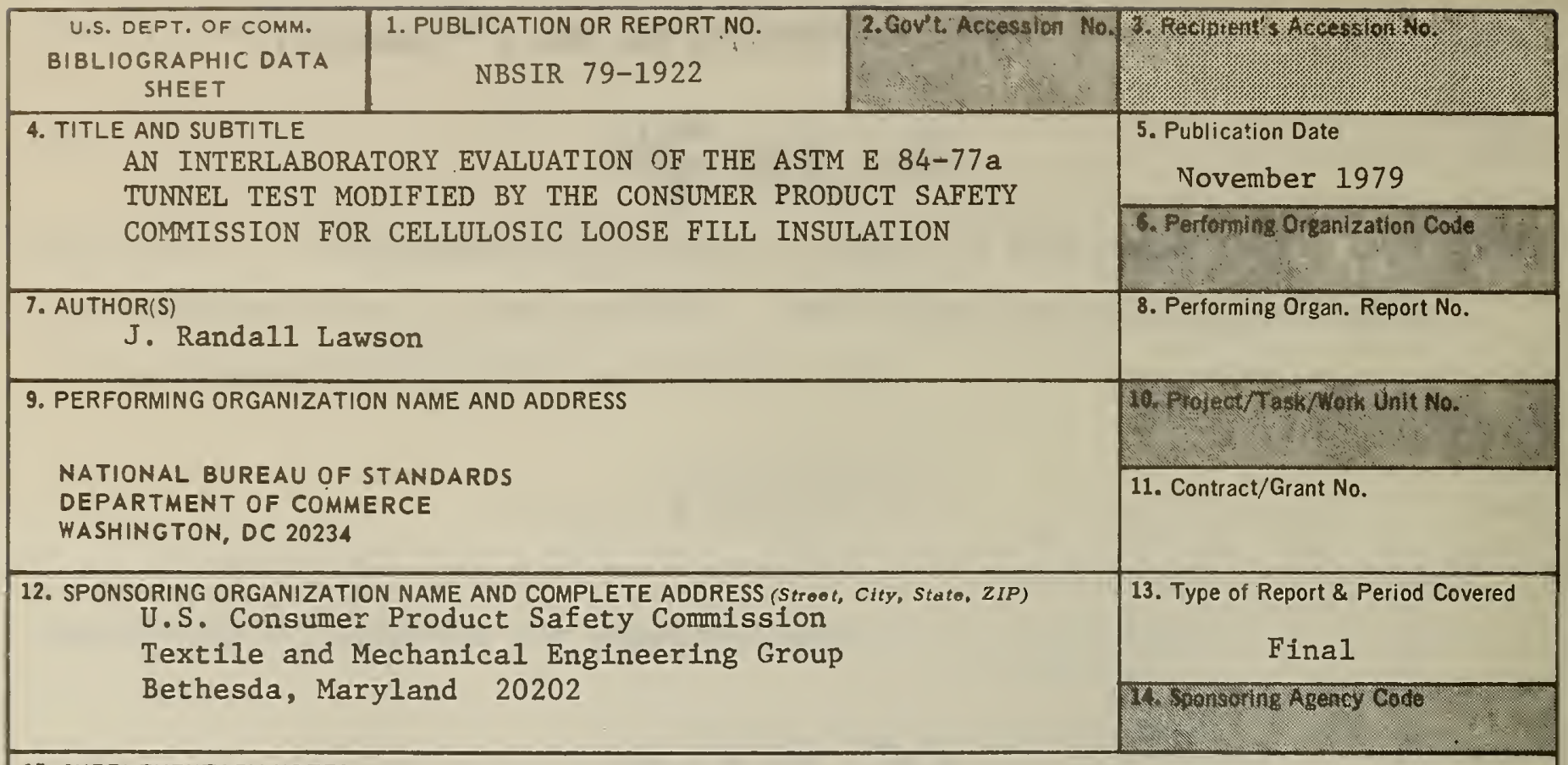

15. SUPPLEMENTARY NOTES

Document describes a computer program; SF-185, FIPS Software Summary, is attached.

16. ABSTRACT (A 200-word or loss factual summary of most sigrificant information. If document includes a significant bibliography or literature survoy, mention it hero.)

An interlaboratory evaluation was conducted to determine precision estimates for repeatability and reproducibility of the American Society for Testing and Materials (ASTM) E 84-77a tunnel test as modified by the Consumer Product Safety Commission for cellulosic loose fill insulation. Six laboratories participated in this study by running tunnel tests on eight cellulosic loose fill materials. Each laboratory was surveyed during the project to examine its conformance with the critical details of the test apparatus and procedure. The results of the survey showed that none of the tunnels completely conformed with the specifications of the modified ASTM E 84-77a standard.

The within-laboratory coefficients of variation for repeatability for the six fire-retardant treated cellulosic insulations ranged from 11 to 23 percent with an average of 16 percent. The between-laboratory coefficients of variation for reproducibility for the same materials ranged from 31 to 41 percent with an average of 35 percent. There would be little assurance that different laboratories would be able to distinguish between ingulations which do and which do not comply with the CPSC mandatory level (FSC $\leq 25$ ) on a consistent basis.

17. KEY WORDS (oix to twolve ontrioo; alphabotical ordor; capitalize only the firat lettor of the firat key word unleas a propor name; ooparated by somicolona)

Cellulosic insulation; flame spread; interlaboratory evaluation; precision; test methods; tunnel test.

18. AVAILABILITY

[x] Unlimited

For Official Distribution. Do Ilot Release to NTIS

Order From Sup. of Doc. U.S. Government Printing Office, Washington, DC 20402, SD Stock No. SN003-003.

$X$ Order From National Technical Information Service (NTIS), Springfield, VA. 22161

\begin{tabular}{|l|c|}
\hline $\begin{array}{l}\text { 19. SECURITY CLASS } \\
\text { (THIS REPORT) }\end{array}$ & $\begin{array}{c}\text { 21. NO. OF } \\
\text { PRINTED PAGES } \\
\text { UNCLASSIFIED }\end{array}$ \\
\hline $\begin{array}{l}\text { 20. SECURITY CLASS } \\
\text { (THIS PAGE) }\end{array}$ & 34 \\
UNCLASSIFIED & $\$ 4.00$ \\
\hline
\end{tabular}


